\title{
Megaselia Rondani (Diptera: Phoridae) larvae as a Sphingidae (Lepidoptera) parasitoid
}

\author{
Larvas de Megaselia Rondani (Diptera: Phoridae) \\ como parasitoide de Sphingidae (Lepidoptera)
}
Thiago Sampaio de Souza * (D), Elen de Lima Aguiar-Menezes ${ }^{1}$ (D), André Luis Santos Resende ${ }^{1}$, Thalles Platiny Lavinscky Pereira² ${ }^{2}$, Vinícius Siqueira Gazal ${ }^{1}$

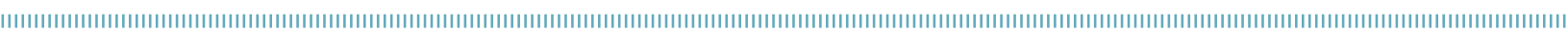

\begin{abstract}
Detritivoria and parasitism are dietary habits already registered for the phorids of the genus Megaselia Rondani. The results of this study confirm the parasitic habit of Megaselia larvae. This is the first Pachylia ficus (Linnaeus, 1758) (Lepidoptera: Sphingidae) adult record as a host of Megaselia scalaris (Loew, 1866) and Megaselia sp. (Diptera: Phoridae).
\end{abstract}

KEYWORDS: phoridae; parasitoid-host relationship; moth.
RESUMO: Detritivoria e parasitismo são hábitos alimentares já registrados para os forídeos do gênero Megaselia Rondani. Os resultados do presente estudo confirmam o hábito parasitário das larvas de Megaselia. Este é o primeiro registro de adulto de Pachylia ficus (Linnaeus, 1758) (Lepidoptera: Sphingidae) como hospedeiro de Megaselia scalaris (Loew, 1866) e Megaselia sp. (Diptera: Phoridae).

PALAVRAS-CHAVE: forídeos; relação parasitoide-hospedeiro; mariposa. 
The Phoridae (Insecta: Diptera) family gathers 4,000 species distributed in 289 genera present in all biogeographic regions of the world, and in Brazil about 850 species are known (DISNEY, 1990, 1994; DISNEY et al., 2010; PEREIRA et al., 2015; AMENT; PEREIRA, 2017). Because of their great diversity of species, Phoridae differs widely as to its eating habits in the larval and adult stages. They can be scavengers, consuming animal remains and other decaying materials, fungi growers, herbivores, predators and parasitoids, causing agents of myiasis in man (DISNEY, 1994; CELIS, 2013; PEREIRA et al., 2015). These different habits of Phoridae make ecosystems dynamic, as they can meet different ecological services.

The aim of this study was to report the parasitism of Megaselia scalaris (Loew, 1866) (Diptera: Phoridae) and of a morphospecies of Megaselia in Sphingidae (Lepidoptera).

On July 7, 2014, a lepidopteran adult of the Sphingidae family was found on the Central Pavilion floor of the Universidade Federal Rural do Rio de Janeiro (UFRRJ), Seropédica Campus, Rio de Janeiro, Brazil (22\%45'S, 4341'W, altitude of $33 \mathrm{~m}$ ), and it was inert, but, when touched, it held very short flights. The adult was collected manually and taken to the laboratory of the Integrated Center for Pest Handling (Centro Integrado de Manejo de Pragas - CIMP)/UFRRJ, in which it was packed in a transparent plastic container of $1 \mathrm{~L}$, sealed with a perforated plastic lid and covered with polyvinyl chloride (PVC) film, and it remained alive for a few hours after its collection. The moth was then identified as belonging to the Pachylia ficus (Linnaeus, 1758) (Lepidoptera: Sphingidae) species, based on BOONE (2016).

On the day after the collection, dipterous larvae were observed around the moth inside the container. On July 12, 2014 (five days after the collection of the lepidopteran), more larvae were observed coming out of the moth. One week after collection, the larvae became pupae. Most adult dipterans emerged between the 16th and 20th days after collection, and more adults were observed coming from inside the moth between the 25th and 27th days after collection. All adult dipterans were removed from the container and placed in a 30-mL glass vial containing $90 \%$ alcohol for specific identification. The lepidopteran adult was observed during 30 days, but there was no emergence of more individuals. After this period, the moth was dissected to observe the presence of pupae that did not result in emergence of adults. After the total observation period, 134 specimens of flies were obtained. Dipterans were identified at a specific level, using morphological characters and following the BORGMEIER (1962) key. All flies belonged to the Megaselia (Diptera: Phoridae) genre. The total of 47 flies (17 males and 30 females) were identified as M. scalaris (Fig. 1), and 87 flies (32 males and 55 females) as Megaselia sp. morphotype, suggesting a case of multiparasitism. This is the first record of M. scalaris and Megaselia sp. as $P$. ficus adult parasitoids. Insects identified were deposited at the Entomological Collection Costa Lima (Coleção Entomológica Costa Lima - CECL) (record no.: 12,508), Department of Entomology and Phytopathology (Departamento de Entomologia e Fitopatologia - DEnF)/ UFRRJ (Seropédica, RJ, Brazil). Megaselia scalaris had already been reported as parasitoids of immature forms of pest species of Noctuidae (Lepidoptera) in agricultural crops (CHACÓN DE ULLOA; ROJAS DE HERNANDEZ, 1981; TEFERA, 2004; RUÍZ-NÁJERA et al., 2007; BERTA et al., 2009), and may present as an important way to control agricultural and forest pests.

\section{ACKNOWLEDMENTS}

The authors thank Dr. Geraldo Salgado Neto (Department of Phytosanitary Defense, Universidade Federal de Santa Maria), by the identification of Pachylia ficus (Linnaeus, 1758) (Lepidoptera: Sphingidae). This study was financed in part by the Coordenação de Aperfeiçoamento de Pessoal de Nível Superior - Brasil (CAPES) - Finance Code 001.
A

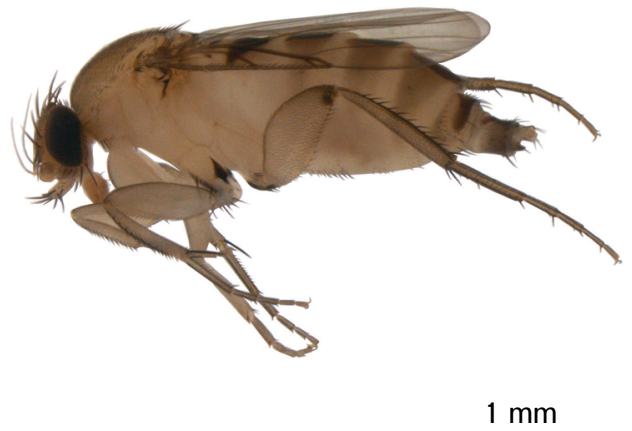

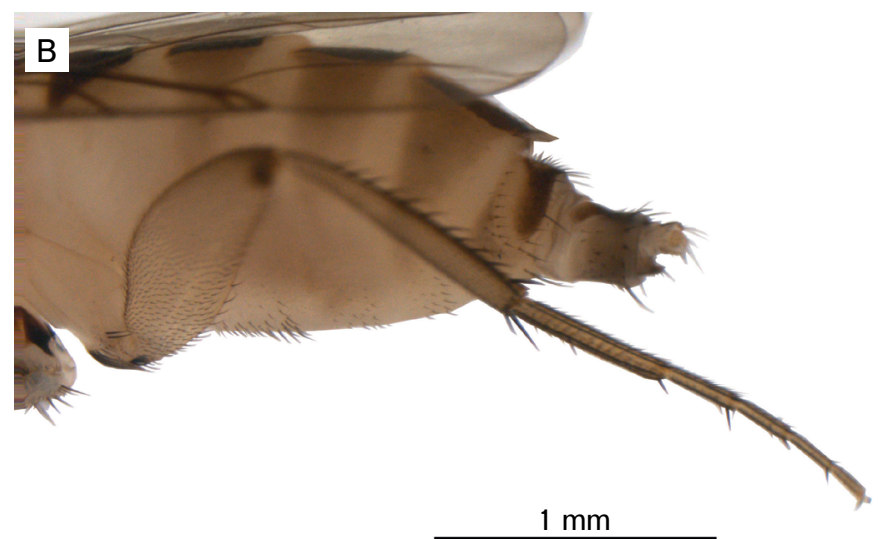

Figure 1. Megaselia scalaris Loew (Diptera: Phoridae): (A) female; (B) female abdomen side view, showing the genitalia. 


\section{REFERENCES}

AMENT, D.C.; PEREIRA, T.P.L. Phoridae in Catálogo Taxonômico da Fauna do Brasil. PNUD. 2017. Available from: <http://fauna.jbrj. gov.br/fauna/faunadobrasil/183530>. Access on: Feb. 212017.

BERTA, D.C.; COLOMO, V.M; VALVERDE, L.; SUELDO, M.R.; DODE, M. Aportes al conocimiento de los parasitoides de larvas de Noctuidae (Lepidoptera) en el cultivo de soja en Tucumán Argentina. Acta Zoológica Lilloana, v.53, n. 1-2, p.16-20, 2009.

BOONE, M. Mississippi Entomological Museum at the Mississippi State University, 2016. Available from: <http://mothphotographersgroup.msstate.edu/species. php?hodges $=7841$ > . Access on: May 82017 .

BORGMEIER, T. Versuch einer Uebersicht ueber die neotropischen Megaselia- Arten, sowie neue oder wenig bekannte Phoriden verschiedener Gattungen (Diptera, Phoridae). Studia Entomologica, Petropolis, v.5, p.289-488, 1962.

CELIS, S.U. Fóridos (Díptera: Phoridae) asociados al hábitat de hormigas cortadoras de hojas (Atta cephalotes y Acromyrmex octospinosus) y sus patrones de localización en un bosque seco tropical andino. Thesis (Mestrado em Ciências) - Universidad Nacional de Colombia, Medellín, 2013.

CHACÓN DE ULLOA, P.; ROJAS DE HERNANDEZ, M. Biología y control natural de Peridroma saucia, praga de la flor de la curuba. Revista Colombiana de Entomología, v.7, n. 1/2, p.47-53, 1981.
DISNEY, R.H.L. Some myths and the reality of scuttle fly biology. Antenna (London), v. 14, n.2, p.64-67, 1990

DISNEY, R.H.L. Scuttle flies: the phoridae. London: Chapman \& Hall, 1994. 467p.

DISNEY, R.H.L.; TAYLOR, S.J.; SLAY, M.E. Review of the scuttle flies (Diptera: Phoridae) recorded from caves in the USA, with new records from Arkansas and Missouri. Subterranean Biology, v.7, p.75-96, 2010.

PEREIRA, T.P.L.; SILVA-FREITAS, J.M.; BRAVO, F.R. Parasitoides e outros inimigos naturais das formigas Poneromorfas. In: J.H.C. DELABIE; R.M. FEITOSA; J.E. SERRÃO; C.S.F. MARIANO; MAJER, J.D. (Eds.). As formigas poneromorfas do Brasil. Ilhéus: Editus, 2015. p.403-424.

RUIIZ-NÁJERA, R.E.; MOLINA-OCHOA, J.; CARPENTER, J.E.; ESPINOSA-MORENO, J.A.; RUIIZ-NÁJERA, J.A.; LEZAMAGUTIÉRREZ, R.; FOSTER, J.E. Survey for hymenopteran and dipteran parasitoids of the fall armyworm (Lepidoptera: Noctuidae) in Chiapas, Mexico. Journal of Agricultural and Urban Entomology, v.24, n.1, p.35-42, 2007. https://doi. org/10.3954/1523-5475-24.1.35

TEFERA, T. Lepidopterous stem borers of sorghum and their natural enemies in eastern Ethiopia. Tropical Science, v.44, n.3, p.128-130, 2004. https://doi.org/10.1002/ts.153 